\title{
Influence of fly ash mixtures on early tree growth and physicochemical properties of soil in semi-arid tropical Alfisols
}

\author{
V. Ramesh · G. R. Korwar · Uttam Kumar Mandal · Jasti V. N. S. Prasad • \\ Kishori Lal Sharma $\cdot$ Yezzu S. Ramakrishna $\cdot$ Kandula Venkanna
}

Published online: 24 April 2008

(C) Springer Science+Business Media B.V. 2008

\section{Erratum to: Agroforest Syst (2008) 73:13-22 \\ DOI 10.1007/s10457-008-9108-7}

The sixth and seventh authors' names were misrepresented in the original publication.

The online version of the original article can be found under doi:10.1007/s10457-008-9108-7.

V. Ramesh · G. R. Korwar · U. K. Mandal .

J. V. N. S. Prasad · K. L. Sharma · Y. S. Ramakrishna •

K. Venkanna

Central Research Institute for Dryland Agriculture,

Santhoshnagar, Hyderabad 500 059, India

V. Ramesh ( $₫)$

Central Tuber Crops Research Institute,

Thiruvananthapuram 695 017, Kerala, India

e-mail: varadharajan_ramesh@rediffmail.com 